\title{
MENIMBANG URGENSI UKHUWAH WATHANIYAH DALAM KASUS INTOLERANSI BERAGAMA DI INDONESIA
}

\author{
Gusnanda \\ Universitas Islam Negeri (UIN) Imam Bonjol Padang, eljambaki46@gmail.com \\ Nuraini \\ Institut Agama Islam Negeri (LAIN) Bukittinggi, chaniago.aini01@gmail.com
}

\begin{tabular}{l|l|l} 
Diterima: 01 Mei 2020 & Direvisi : 23 Juni 2020 & Diterbitkan: 30 Juni 2020
\end{tabular}

\begin{abstract}
This paper discusses the phenomenon of religious intolerance in Indonesia. The spreading of various cases of intolerance lately is a big test for the integrity of Unity of the Indonesian Republic. One religion that is often cornered in the case of intolerance is Islam. Perhaps this is caused by many cases of radicalism, terrorism, and other social unrest carried out by Muslims. This assumption needs to be clarified because Islam never teaches its adherents to intolerance. Amid the undermining of this intolerant virus, love is needed in the motherland. In the Islamic paradigm, it is called Ukhuwah Wathaniyah or national brotherhood. This fraternity which was built with Ukbuwah Wathaniyah put the interests and love of the nation above all else. This conception of Ukhuwah Wathaniyah was practised by the Prophet Muhammad SAW. when he built a Medina society fourteen centuries ago. In the Indonesian Context, the concept of Ukhuwah $W$ athaniyah needs to be re-actualized to realize religious tolerance in Indonesia.
\end{abstract}

Keywords: Intolerance, Religious Tolerance, Madina Charter, Ukbuwab Wathaniyah.

\begin{abstract}
Abstrak
Tulisan ini membahas tentang fenomena intoleransi beragama di Indonesia. Menjamurnya berbagai kasus intoleransi atas dasar agama belakangan ini menjadi ujian besar bagi keutuhan NKRI (Negara Kesatuan Republik Indonesia). Salah satu agama yang sering disudutkan dalam kasus intoleransi ini adalah Islam. Barangkali ini disebabkan oleh banyaknya kasus radikalisme, terorisme, dan kerusuhan sosial lainnya dilakukan umat muslim. Anggapan ini perlu diluruskan karena Islam tidak pernah mengajarkan penganutnya berbuat intoleran. Di tengah rongrongan virus intoleransi ini diperlukan rasa cinta pada tanah air. Dalam paradigma Islam disebut ukhuwah wathaniyah atau persaudaraan yang didasarkan atas sesama anak bangsa. Ikatan persaudaraan yang dibangun dengan ukbuwah wathaniyah ini meletakkan kepentingan dan kecintaan terhadap bangsa di atas segalanya. Konsepsi tentang ukhuwah wathaniyah ini telah dipraktikkan Nabi Muhammad SAW. ketika membangun masyarakat Madinah empat belas abad yang lalu. Dalam Konteks Indonesia, konsep ukhuwah wathaniyah ini perlu diaktualisasikan kembali untuk mewujudkan toleransi beragama di Indonesia.
\end{abstract}

Kata Kunci: Intoleransi, Toleransi Beragama, Piagam Madinah, Ukhuwah Wathaniyah. 


\section{PENDAHULUAN}

Alwi Shihab dalam bukunya Examining Islam in The West menyebutkan betapa Indonesia adalah negeri yang luas. Secara geografis, lebih dari 17.000 pulau di negeri ini terbentang dari Sabang hingga Merauke, sebanding luasnya antara Los Angeles hingga New York. ${ }^{1}$ Luasnya teritorial tersebut diimbangi pula dengan populasi penduduknya. Pada tahun 2010 saja populasi penduduk Indonesia berjumlah 238,5 juta jiwa. Angka ini diproyeksikan akan terus mengalami peningkatan dari tahun ke tahun. ${ }^{2}$ Berdasarkan data terbaru yang dirilis Badan Pusat Statistik (BPS) Indonesia pada tahun 2019 bahwa populasi penduduk Indonesia saat ini telah mencapai 265,3 juta jiwa. ${ }^{3}$ Dari jumlah penduduk tersebut berkembang lebih dari tiga ratus kelompok etnis yang berbeda-beda dan masing-masingnya mempunyai identitas budayanya sendiri. Tidak hanya itu, dari sisi bahasa juga terdapat lebih dari dua ratus lima puluh bahasa yang berbeda digunakan masayarakat dalam kehidupan seharihari. Bahkan, hampir semua agama besar-selain dari agama asli yang jumlahnya banyak sekalidianut oleh sebagian besar masyarakatnya. ${ }^{4}$ Data dan fakta ini menunjukkan bahwa Indonesia merupakan bangsa yang begitu majemuk.

Bagaimanapun, semua anak bangsa di negeri ini harus menerima kenyataan sebagai bangsa yang majemuk itu. Kenyataan keberagaman ini merupakan "karunia" Tuhan yang tidak bisa ditolak sedikitpun. Kesadaran akan keberagaman mestinya mendorong seseorang mampu hidup dengan rukun dan damai. Sebab, kerukunan adalah salah satu kunci membangun kehidupan yang toleran.

1 Alwi Shihab, Examning Islam in The West; Addessing Accusation and Correcting Misconceptation (Jakarta: Gramedia, 2011), 1.

2 Tim Penyusun, Proyeksi Penduduk Indonesia Tabun 2010-2035 (Jakarta: BPS, 2013), 23.

3 Tim Penyusun, Statistik. Indonesia 2019 Jakarta: BPS, 2019), 81.

4 Faisal Ismail, Republik Bhineka Tunggal Ika; Mengurai Isu-Isu Konflik, Multikulturalisme, Agama Dan Sosial Budaya (Jakarta: Litbang dan Diklat Kemenag, 2012), 11.
Dalam catatan sejarah perjalanan negeri ini, kemajemukan beberapa kali justru menimbulkan ketegangan dan perpecahan. Keragaman tidak lagi menjadi "anugerah" malah menjadi "malapetaka" yang menghantui keutuhan negeri ini. Di antara bentuk penolakan terhadap kemajemukan itu adalah pelanggaran kebebasan beragama atau berkeyakinan, perusakan rumah ibadah, diskriminasi atas dasar agama, dan penghentian kegiatan keagamaan.

Hasil penelitian The Wahid Institute menyebutkan bahwa sepanjang tahun 2018 saja telah terjadi 192 kasus pelanggaran kebebasan beragama dan berkeyakinan. Kasus ini melibatkan 138 aktor negara dan 148 aktor non-negara. Ironisnya, dari beberapa kasus yang terjadi kelompok Muslim menempati posisi jumlah tertinggi sebagai pelaku pelanggaran dan intoleransi beragama. ${ }^{5}$ Hasil penelitian tersebut tentu saja dapat mencoreng identitas Islam sebagai agama yang toleran dan menghargai hak beragama seseorang.

Di tengah buruknya kondisi toleransi antar umat beragama tersebut, umat Islamsebagai kelompok mayoritas-di negeri ini sebetulnya memikul tugas dan tanggung jawab besar dalam membangun kehidupan yang toleran antar umat beragama. Kesadaran tentang ini sangat diperlukan untuk menjaga kesucian ajaran Islam itu sendiri dari stigma-stigma yang negatif. Sebab, pada dasarnya ajaran Islam memiliki visi misi untuk terwujudnya kehidupan masyarakat yang egaliter dan menghargai sesama. Oleh karena itu, untuk menjernihkan kekeruhan hubungan antarumat bergama di negeri ini perlu dicari solusinya, agar bangsa ini khususnya umat Islam tetap menjadi "uswatun hasanah" dan lokomotif dalam menyuarakan sekaligus menghadirkan toleransi di Indonesia. Salah satu upaya yang bisa dilakukan adalah dengan mempertegas rasa nasionalisme. Dalam konsepsi Islam disebut dengan istilah " Ukhuwah wathaniyab".

5 Yenny Zannuba Wahid, Laporan Tabunan Kebebasan Beragama Berkeyakinan 2018 (Jakarta: The Wahid Institute, 2018), 21-24. 


\section{WAJAH AGAMA DAN TOLERANSI DI INDONESIA}

Sebagaimana ditegaskan di awal tulisan ini bahwa Indonesia merupakan suatu bangsa pluralistik. Panorama kemajemukannya meliputi berbagai dimensi, mulai dari dimensi agama, tradisi, kesenian, budaya, hingga standar nilai dan norma yang di anut masyarakatnya. Keragaman ini mengandung potensi positif dan sekaligus negatif. ${ }^{6}$ Di satu sisi ia memiliki kekuatan konstruktif apabila disikapi secara tepat. Namun, di sisi lain ia malah dapat berubah menjadi kekuatan destruktif yang membahayakan integritas nasional. ${ }^{7}$ Dari pelbagai keragaman yang dimiliki, perbedaan agama dan keyakinan menjadi salah satu masalah keberagaman yang sangat sensitif.

Meskipun Indonesia bukan negara yang didasarkan pada agama, namun dalam praktik sosial, ekonomi, khususnya praktik politik kenegaraannya, nilai-nilai agama tetap menjadi bagian penting dan tidak bisa ditinggalkan. ${ }^{8}$ Kuatnya pengaruh agama dalam setiap dimensi itu terkadang membuat ketegangan-ketegangan sosial dan tak jarang berujung konflik. Keterlibatan dimensi agama dalam masalah politik dapat dilihat pada pelaksanaan pemilihan umum presiden tahun 2014 lalu yang kental dengan fenomena "instrumentalisasi agama". Fenomena itu memperlihatkan bahwa agama dijadikan simbol untuk meraih dukungan dari masyarakat. Kejadian serupa kembali terjadi pada pemilihan

6 Buyung Syukron, "Agama Dalam Pusaran Konflik (Studi Analisis Resolusi Terhadap Munculnya Kekerasan Sosial Berbasis Agama Di Indonesia)," Ri'ayah: Jurnal Sosial Dan Keagamaan 2, no. 01 (December 14, 2017): 2, https://doi.org/10.32332/riayah.v2i01.960.

${ }^{7}$ Ismail, Republik. Bbineka Tunggal Ika; Mengurai IsuIsu Konflik, Multikulturalisme, Agama Dan Sosial Budaya, 12.

8 Zuly Qodir, "Kaum Muda, Intoleransi, Dan Radikalisme Agama," Jurnal Studi Pemuda 5, no. 1 (August 9, 2018): 429-45,

https://doi.org/10.22146/studipemudaugm.37127.

9 Nur Kafid, “Agama Di Tengah Konflik Sosial: Tinjauan Sosiologis Atas Potensi Konflik Keberagaman Agama Di Masyarakat," Al-A'raf: Jurnal Pemikiran Islam Dan Filsafat 12, no. 1 (June 30, 2015): 1-13, https://doi.org/10.22515/ajpif.v12i1.1180. gubernur DKI Jakarta tahun 2016. Isu yang dingkat adalah penistaan agama oleh Basuki Cahaya Purnama alias "Ahok" yang saat itu juga sebagai salah satu calon gubernur. Ahok dituduh telah melakukan penistaan terhadap agama Islam karena pernyataannya tentang surat al-Maidah ayat 51. Pernyataannya tersebut kemudian dikapitalisasi sehingga melahirkan gejolak protes besar-besaran. Untuk mengkapitalisasi isu ini dilakukan berbagai propaganda melalui media sosial seperti Facebook, Instragram, dan aplikasi personal seperti WhatsApp. Mobilasasi massa melalui media pun berhasil dan lahirlah gerakan aksi yang dikenal Gerakan 212. ${ }^{10}$

Dalam konteks politik, sejauh ini instrumen agama agaknya sangat efektif dalam membuat propaganda politik di Indonesia. Hal tersebut dapat diamati kembali pada pemilihan presiden di tahun 2019. Berbagai isu agama pun muncul dalam kontestasi sekali lima tahun itu, seperti isu PKI bangkit lagi, partai setan versus partai Allah, isu khilafah, dan sebagainya.

Bagi elit politik, isu agama ini tentu hanya menjadi isu musiman yang paling dibutuhkan ketika musim politik. Ketika musim itu selesai mereka tidak mau tau dengan dampak dari isu yang dipropagandakan. Padahal, dampaknya sangat mengganggu sendi-sendi kehidupan masyarakat. Di antaranya adalah terjadinya polarisasi masyarakat, hilangnya kepercayaan publik, dan semakin meningginya rasialisme atas nama ideologi, partai politik, suku dan bahkan agama. Dalam tahap tertentu, rasa kebencian itu semakin mendalam dan dikhawatirkan akan menyebabkan konflik yang lebih besar. Di sisi lain, fenomena kapitalisasi agama ini menimbulkan keretakan huhubungan dalam intern umat beragama dan lebih lagi ketegangan dalam hubungan eksternal/antarumat beragama. Sekali lagi, dalam konteks ini wajah agama di

10 Arie Setyaningrum Pamungkas and Gita Octaviani, "Aksi Bela Islam Dan Ruang Publik Muslim: Dari Representasi Daring Ke Komunitas Luring," Jurnal Pemikiran Sosiologi 4, no. 2 (November 6, 2017): 65-87, https://doi.org/10.22146/jps.v4i2.28581. 
Indonesia cenderung hanya dijadikan sebagai simbol dan tameng semata. Atas alasan inilah agama menjadi sangat berpotensi sebagai faktor pemicu lahirnya kekerasan, konflik, dan intoleransi atas dasar agama di negeri ini.

Apabila ditelaah lebih lanjut dapat disimpulkan bahwa agama nampaknya menjadi sesuatu yang sangat "seksi" dan menampilkan peran yang sangat besar dalam menjaga kerukunan beragama, berbangsa, dan bernegara. Oleh sebagian kalangan, agama diyakini sebagai salah satu sumber permasalahan yang terjadi. Orang dapat menjadi pengasih karena agama. Namun, di sisi lain orang juga dapat menjadi ganas dan membunuh manusia lain juga karena alasan agama. Pandangan semacam ini telah banyak diingatkan para ahli, misalnya Calton sebagaimana dikutip M. Zainuddin Daulay menyebutkan bahwa "manusia bisa bertengkar untuk agama, bisa menulis tentang agama, bisa membunuh dan terbunuh karena agama, apa saja dapat ia lakukan untuk agama; kecuali melakoni agama". ${ }^{11}$ Pernyataan ini sekali lagi menegaskan bahwa agama sangat berperan menentukkan watak manusia. Agama punya kontribusi besar dalam konflik dan perang yang terjadi antara sesama manusia. Oleh karena itu, mestinya dari ungkapan tersebut dapat membangunkan kesadaran manusia dalam merefleksikan secara jujur bagaimana hakikat sebuah agama, yang seharusnya dapat meredam kekerasan, radikalisme, dan tindakan ekstrimisme lainnya.

Secara normatif, setiap penganut agama pasti meyakini tidak ada satupun dari ajaran agamanya yang menganjurkan kekerasan dan intoleransi. Pandangan semacam ini tentu saja terdapat dalam konsep-konsep ideal di setiap agama. Akan tetapi, apabila dilihat dalam dunia realitas maka ternyata banyak sekali ditemukan kekerasan-kekerasan yang mengatasnamakan agama.

11 M. Zainuddin Daulay, ed., Mereduksi Eskalasi Konflik Antar Umat Beragama Di Indonesia (Jakarta: Litbang dan Diklat Kemenag, 2012), 57.
Menilik perjalanan sejarah bagaimana relasi agama dan konflik di Indonesia sungguh merupakan pemandangan yang mengerikan. Banyak sekali konflik yang didasari atas dasar agama. Pertikaian antar umat beragama ini menjadi bagian yang tidak terpisahkan dari drama kehidupan bangsa Indonesia yang notabenenya sebagai bangsa yang plural. Menurut M. Amin Abdullah, kerusuhan yang dipicu alasan agama telah berlangsung sejak Indonesia merdeka. Kasus tersebut semakin meningkat menjelang era reformasi, misalnya tragedi Pekalongan (1995), Tasikmalaya (1996), Rengasdengklok (1997), Sanggau Ledo, Kalimantan Barat (1996 dan 1997) sampai yang terjadi di Ambon dan Maluku. ${ }^{12}$ Kemudian pada Januari tahun 2000 terjadi konflik antara umat Islam dan umat Kristen di Pulau "Seribu Mesjid", Nusa Tenggara Barat. Tragedi yang dikenal sebagai "Tragedy One Seven One" ini menyebabkan dua belas gereja habis dibakar dan dirusak, puluhan rumah penduduk menjadi sasaran, dan menewaskan lima orang korban jiwa. $^{13}$

Tragedi berdarah atas dasar agama ini semakin menyeruak ke permukaan terutama semenjak meletusnya era reformasi hingga saat ini. Bahkan, pascareformasi telah dianggap sebagai era di mana semakin tingginya eskalasi sikap intoleransi beragama terjadi. ${ }^{14}$ Hasil studi ini juga senada dengan penelitian Zuly Qodir yang dalam salah satu tulisannya menyebutkan bahwa kasus kekerasan atas dasar agama sangat banyak terjadi dalam kurun waktu 2009-2013. Dalam

12 M Amin Abdullah, "Pengajaran Kalam Dan Teologi Di Era Kemajemukan," Jurnal Tashwirul Afkar, no. 11 (2001): 6.

13 Mahsun Mahsun, "Tragedi Di Pulau 'Seribu Mesjid': Konflik Agama Atau Perlawanan Budaya?," Antropologi Indonesia, no. 63 (July 21, 2014): 81-90, https://doi.org/10.7454/ai.v0i63.3403.

14 Andik Wahyun Muqoyyidin, "Potret Konflik Bernuasa Agama Di Indonesia (Signifikansi Model Resolusi Berbasis Teologi Transformatif)," Analisis XII, no. 2 (2012): 315-40; Engki Prasutomo, Hengki Wijaya, and Ivan Th. J Weismann, "The Role of Public Sphere According to Jurgen Habermas's Perspective for Multicultural Societies in the Indonesia Context," FUADUNA: Jurnal Kajian Kegamaan Dan Kemasyarakatan 02, no. 02 (2018): 43-54. 
studi yang ia lakukan tersebut ditemukan sekitar 56 kasus intoleransi beragama di Indonesia. ${ }^{15}$

Buruknya sikap toleransi beragama di Indonesia belakangan ini dapat dilihat dari konflik SARA di Tanjung Balai Asahan Sumatera Utara (30 Juli 2016). Konflik anarkis atas dasar agama ini disebutkan berawal dari protes seorang wanita keturunan Tionghoa M (41) kepada takmir Masjid Al-Makhsum untuk mengecilkan volume suara azan di masjid karena merasa terganggu. Teguran tersebut katanya telah dilayangkan beberapa kali. Namun, beberapa waktu kemudian takmir masjid datang bersama jamaah mendatangi $M$ di rumahnya, Jalan Karya, Tanjung Balai, pada Jumat 29 Juli 2016. Aksi tersebut berhasil dicegah, dan kumpulan massa berangsur pulang. Akan tetapi, karena terprovokasi postingan media sosial, massa tersebut kembali mendatangi rumah M (41) untuk menghancurkan dan membakar rumah tersebut. Namun aksi tersebut dapat digagalkan oleh warga kompleks setempat. Tak puas dengan kejadian itu, ratusan warga pun kemudian mendatangi Vihara dan Klenteng dan membakarnya. ${ }^{16}$

Ada beberapa hal yang patut dicatat dari peristiwa intoleransi beragama di Tanjung Balai ini. Pertama, penggunaan media sosial yang tidak hati-hati di era digital dapat menyebabkan terjadinya konflik yang besar. Kedua, kejadian ini membuktikan buruknya kualitas komunikasi dan ekspresi beragama antar umat Islam dan Budha di ruang publik. Kejadian ini bukan saja cerita tentang Tanjung Balai saja, namun ini semua merupakan "teks sosial" kita yang memperlihatkan tentang wajah toleransi Indonesia yang runyam dan memilukan. Peristiwa Tanjung Balai telah menjadi simbol terkoyaknya rasa kemanusiaan dan persatuan bangsa kita dalam beragama, berbangsa dan bernegara. Ketiga, dalam kasus ini kelompok Islam lagi-lagi menjadi

15 Qodir, "Kaum Muda, Intoleransi, Dan Radikalisme Agama."

${ }^{16}$ Syukron, "Agama Dalam Pusaran Konflik (Studi Analisis Resolusi Terhadap Munculnya Kekerasan Sosial Berbasis Agama Di Indonesia)." "oknum" pelaku kekerasan yang didorong oleh rasialisme SARA.

Dalam studi terbaru yang dilakukan Setara Institut pada tahun 2018, tercatat 160 kasus pelanggaran kebebasan beragama atau berkeyakinan dengan 202 bentuk tindakan dan tersebar di 25 provinsi. Hasil riset ini memperkuat data yang dirilis The Wahid Institute sebagaimana yang diutarakan sebelumnya dan menunjukkan bahwa fenomena intoleransi beragama benarbenar nyata dan bukan isu ataupun hoaks yang dibangun oleh kelompok tertentu. Dari berbagai kasus yang tercatat sepanjang tahun 2018 terjadi 20 gangguan terhadap rumah ibadah. Sedangkan pelanggaran KBB (Kebebasan Beragama atau Berkeyakinan) paling banyak menimpa warga yaitu sekitar 39 kasus. $^{17}$

Data-data dan pelbagai realitas tentang kasus intoleransi beragama yang diutarakan di atas merupakan bukti buruknya wajah toleransi beragama di Indonesia. Rangkaian tindakan intoleransi itu menunjukkan masih terjadinya hegemoni dan dominasi dari kelompok mayoritas terhadap kelompok minoritas. Artinya, praktikpraktik diskriminasi terhadap kelompok minoritas dapat menjadi penghalang terbangunnya harmonisasi antar umat bergama. Kondisi ini sebetulnya juga menjadi ancaman bagi terwujdudnya demokrasi majemuk di Indonesia. Sebab, dalam konsep demokrasi tidak ada kelompok-kelompok yang terdominasi atau tersingkir atas desakan kelompok dominan manapun. ${ }^{18}$ Jadi, selama praktik intoleransi masih berkembang maka nonsense berbicara demokrasi yang menjanjikan terbangunnya civil society yang salah satu indikatornya menjamin kebebasan dan toleransi beragama.

Kembali pada pembicaraan sejauh mana pengaruh agama terlibat dalam kasus-kasus

17 Halili, "Siaran Pers Setara Institute, 'Melawan Intoleransi Di Tahun Politik: Kondisi Kebebasan Beragama/Berkeyakinan Dan Pemajuan Toleransi Di Indonesia Tahun 2018"' (Jakarta, 2019).

18 Sudarto, "Recognisi Agama Lokal Prasyarat Menuju Demokrasi Majemuk," FUADUNA: Jurnal Kajian Kegamaan Dan Kemasyarakatan 02, no. 02 (2018): 92-105. 
kekerasan dan intoleransi. Sebagaimana dijelaskan sebelumnya bahwa dalam sebuah konflik posisi agama seringkali hanya diposisikan sebagai tameng dan alat untuk melampiaskan emosi. Agama seakan diperkosa untuk mewujudkan tujuan pribadi dan kelompok tertentu. Sungguh pun demikian, adanya realitas yang membuktikan agama terlibat dalam melahirkan konflik dan kekerasan, sebagaimana dinyatakan dalam datadata di atas tidak dapat pula diterima seutuhnya sebagai tesis bahwa agama mengajarkan kekerasan dan intoleransi. Realitas tersebut hanyalah bagian dari interpretasi yang keliru dari pemeluk agama terhadap teks-teks keagamaannya. Barangkali yang ingin dipertegas di sini, terutama dalam konteks Indonesia adalah kasus-kasus intoleransi dan konflik berbasis agama lahir akibat pertarungan ideologi dan politik yang kemudian menjalar ke dalam konflik agama. Di banyak kasus, agama menjadi mata rantai terakhir konflik karena karena dalam struktur masyarakat Indonesia, agama menjadi dasar psikologi sehingga sangat sensitif terhadap konflik. Kondisi semacam ini, ditopang oleh maraknya alira-aliran sempit baik yang mengejawantah dalam bentuk partai politik, organisasi-organisasi maupun asosiasi-asosiasi. ${ }^{19}$ Jadi, agama boleh saja diyakini sebagai faktor pemicu konflik namun tidak bisa dianggap sebagai satu-satunya apalagi penyebab utama dari sebuah konflik.

Jika agama bukanlah sebagai faktor utama dalam penyebab konflik dan kasus intoleransi beragama yang terjadi di Indonesia, lantas apa faktor yang menjadi penyebabnya? Beberapa riset mengatakan bahwa penyebab kasus intoleransi adalah rasa primodialisme yang berlebihan. Faktor ini dianggap paling berperan dalam konflik yang terjadi di Ambon, Poso, peristiwa Sampit, dan lain-lain. Konflik atas dasar rasa solidaritas kedaerahan ini kemudian ditarik pada isu agama, inilah yang menyebabkan konflik itu semakin

19 Baidi Baidi, "Agama Dan Multikulturalisme: Pengembangan Masyarakat Melalui Pendekatan Agama," Millah ed, no. khus (December 20, 2010): 9, https://doi.org/10.20885/millah.ed.khus.art1. membara. ${ }^{20}$ Pendapat lain mengatakan bahwa konflik yang dilakukan atas dasar agama serigkali terjadi karena diawali dari motif politikekonomi. ${ }^{21}$ Selain itu, ada juga yang meyakini bahwa faktor utama terjadinya kekerasan dalam agama adalah: pertama, bahwa konflik itu menunjukkan dan menggambarkan serta menjelaskan perjuangan suatu kelompok yang selalu dipenuhi kekerasan untuk keperluan dasar seperti keamanan dan lain sebaginya. Kedua, adanya faktor perampasan kebutuhan manusia yang kemudian kemudian diartikulasikan secara kolektif. Kebutuhan manusia yang kemudian dinilai sebagai hak dasar itu adalah keamanan, pengembangan (hak mencari nafkah), akses politik, dan identitas (ekspresi budaya dan religious). Ketiga, adalah faktor pemerintah yang tidak mampu memuaskan kenginan dasar individu dan kelompok identitas. ${ }^{22}$ Meskipun terdapat bantahan-bantahan atas teori ini namun mencermati pelbagai kasus intoleransi yang terjadi di Inonesia maka penulis cenderung setuju dengan argumentasi-argumentasi penyebab konflik berbasis agama di atas.

Berdasarkan teori-teori ini juga maka secara tidak langsung membantah stigma negatif tentang Islam sebagai sebuah agama yang mengajarkan kekerasan dan intoleransi. Dengan begitu, jika agama dianggap bukan sebagai penyebab utama dan hanya sebagai salah satu pemicu lahirnya konflik maka justru agama harus bertanggung jawab terhadap semua konflik yang terjadi. Pertanyaannya, bagaimana tanggung jawab moral umat Islam dalam meredamkan konflik agama yang terjadi.

Untuk menjawab pertanyaan tersebut penulis perlu ditegaskan bahwa masalah

20 Abbas, "Agama Dan Konflik Dalam Masyarakat Di Indonesia," Shautut Tarbiyah-IAIN Kendari 18, no. 2 (2012): 10-17.

${ }^{21}$ Bertrand Jacques, Nationalism and Ethnic Conflict in Indonesia (Cambridge: Cambridge University Press, 2004), 34.

22 Syukron, "Agama Dalam Pusaran Konflik (Studi Analisis Resolusi Terhadap Munculnya Kekerasan Sosial Berbasis Agama Di Indonesia)." 
kebebasan beragama (toleransi beragama) sebetulnya telah lama menjadi keinginan dan perhatian umat Islam, khususnya di Indonesia. Kalaupun akhir-akhir ini suara itu terdengar lebih keras karena memang masih ada fenomena dalam masyarakat yang cenderung mengarah pada upaya mengakibatkan keresahan dalam konteks kebebasan beragama. Baik yang menimpa umat Islam seperti yang terjadi di Timor-Timur maupun yang terjadi di Tasikmalaya, ${ }^{23}$ dan lain lain sebagaimana telah dikemukakan sebelumnya.

Terjadinya kasus intoleransi beragama di Indonesia sebetulnya tidak berdiri sendiri namun berjalin berkelindan dengan faktor lain, seperti ekonomi, politik, dan bhkan lemahnya pengawasan Pemerintah terhadap kelompok tertentu yang mengintimidasi dan memberangus hak-hak kelompok lain dengan kekerasan yang berlindung di balik kesucian agama. ${ }^{24}$ Padahal, secara konstitusional, persoalan hak-hak beragama sudah terdapat regulasi yang mengaturnya. Oleh Djohan Effendi, dikatakan bahwa toleransi beragama di negeri ini telah dijamin undang- undang. Hal itu secara tegas dan jelas tercantum dalam UUD 1945 Pasal 9 ayat 1 dan 2 yaitu: 'Negara berdasarkan asas Ketuhanan Yang Maha Esa. Negara menjamin kemerdekaan tiap tiap penduduk untuk mememeluk agamanya masing masing dan beribadat menurut agama dan kepercayaannya itu". Landasan konstitusi ini bahkan diperjelas lagi oleh TAP MPR tentang P4 (Pedoman Penghayatan dan Pengamalan Pancasila) yang menegaskan bahwa kebebasan beragama merupakan hak yang paling asasi dari manusia. ${ }^{25}$

Meskipun secara teoritis dan konstitusional Negara telah menjamin kebebasan dan mengatur bagaimana untuk hidup rukun

23 Haidlor Ali Ahmad, Dinamika Kebidupan Keagamaan Di Era Reformasi, ed. Haidlor Ali Ahmad (Jakarta: Litbang dan Diklat Kemenag, 2010), 204.

${ }^{24}$ Syukron, "Agama Dalam Pusaran Konflik (Studi Analisis Resolusi Terhadap Munculnya Kekerasan Sosial Berbasis Agama Di Indonesia)," 13.

${ }_{25}$ Ahmad, Dinamika Kehidupan Keagamaan Di Era Reformasi, 237. antar umat beragama, namun sangat paradoks dengan fakta yang terjadi di lapangan dimana masih tingginyanya angka kekerasan dan konflik atas dasar agama tidak kunjung usai. Menurut penulis, tidak adanya konsistensi dalam mengamalkan dan mengejawantahkan aturan konstitusi dengan sungguh-sungguh-baik di kalangan Pemerintah maupun rakyat-dalam kehidupan beragama belakangan ini menjadi salah satu penyebab problema persoalan intoleransi beragama semakin memburuk. Satu-satunya yang dapat menyadarkan bangsa ini untuk konsisten dalam menjalan konstitusi tentang toleransi dan hidup secara harmoni satu sama lain adalah rasa nasionalisme. Sayangnya, rasa nasionalisme inilah yang semakin memudar.

Dari banyak kasus yang terjadi, penulis mempertanyakan satu hal, mengapa antara sesama anak bangsa mau bertikai dan saling membunuh? Jika semua sadar bahwa kita adalah satu bangsa yang majemuk namun menjunjung tinggi rasa persatuan maka tentu pertikaian atas dasar agama tidak akan terjadi. Dengan demikian, dapat dikatakan bahwa memudarnya rasa nasionalisme ini menjadi beban tersendiri dalam mencegah berkembangnya kasus intoleransi beragama. Selain rasa primodialisme, motif ekonomi-politik, dan lemahnya pengasan pemerintah ternyata meredupnya rasa nasionalisme memberikan kontribusi terhadap lahirnya tindakan kekerasan berbau SARA. Faktor inilah yang ingin penulis tekankan untuk menyelesaikan konflik berbasis agama.

\section{DARI UKHUWAH WATHANIYAH KE TOLERANSI BERAGAMA}

Dalam kajian sebelumnya, telah diketengahkan bahwa kekerasan yang melibatkan agama dan penganutnya di negeri seribu etnis ini salah satunya disebabkan oleh hilang dan tenggelamnya rasa kebangsaan dalam jiwa masyarakatnya. Masalah ini harus disikapi secepatnya dengan serius dan dengan hati-hati. Jika tidak, kekerasan dan pertikaian akibat 
perbedaan suku, ras, adat apalagi perbedaan keyakinan (agama) akan terus bergentayangan.

Sebagai umat Islam, meneladani toleransi yang digagas oleh Rasul SAW. adalah pendekatan yang paling utama dalam merefleksikan kebebasan beragama di negeri multi etnis dan multi agama ini. Lahirnya Piagam Madinah merupakan salah satu model kehidupan toleransi beragama yang pernah ada. Oleh sebab itu, menjadi menarik dan penting seandainya hal ini dieksplorasi kembali sebagai upaya menjawab tantangan pluralitas dan toleransi di Indonesia.

Perjalanan pahit dakwah Nabi Muhammad SAW. di Mekah mengantarkan beliau ke Madinah untuk melanjutkan misi kerasulannya. Sebagai seorang pendatang dan minoritas, beliau pun mampu menjadi mediator atas berbagai konflik yang terjadi di kalangan warga Madinah yang plural, terdiri dari beberapa suku dan kabilah serta beberapa penganut agama lain seperti Yahudi, Nasrani, dan Majusi serta mayoritas penyembah berhala.

Umar Hasyim dalam bukunya Toleransi dan Kemerdekaan Beragama dalam Islam menyebutkan setidaknya ada dua suku Arab dan tiga suku Yahudi. ${ }^{26}$ Lebih lanjut dalam keterangannya dipaparkan bahwa perasaan lega Rasul SAW. setelah terbebas dari pengekangan kaum kafir Quraisy di Mekah ternyata menimbulkan kecanggungan baru setibanya di Madinah, khususnya terhadap kalangan Yahudi. Akan tetapi, Nabi SAW. telah memperkirakan kemungkinan buruk yang terjadi antara kaum muslimin dan Yahudi serta kelompok lain, sehinga strategi dan taktik pun telah dipersiapkan. Di antara strategi dan taktik itu adalah mengadakan perjanjian di antara kedua belah pihak. Perjanjian inilah yang kemudian disebut sebelumnya sebagai "Piagam Madinah". Perjanjian ini merupakan salah satu rangka dalam usaha membina masyarakat baru yang sesuai dengan cita cita Islam (masyarakat yang egaliter).

26 Umar Hasyim, Toleransi Dan Kemerdekaan Beragama Dalam Islam Sebagai Dasar Menuju Dialog Dan Kerukunan Antar Agama (Jakarta: PT. Bina Ilmu, 1979), 138.
Ada dua sendi pokok dalam perjanjian ini; pertama adalah hidup berdampingan secara damai dengan semua golongan, baik kabilah Yahudi ataupun kabilah kabilah Arab lainnya. Adapun sendi yang kedua adalah terwujudnya kemerdekaan agama yang tidak hanya diakui oleh Islam tapi harus juga dipertahankan dan dijamin olehnya. ${ }^{27}$ Ringkasnya, susunan masyarakat yang dikendaki oleh Islam ialah masyarakat yang menjunjung tinggi kemanusiaan dan toleransi.

Semenjak kedatangan Nabi SAW di Madinah, semua pertikaian dan pertentangan antara kabilah kabilah yang ada di Madinah, baik antara sesama kabilah Yahudi; suku Aus dan Khazraj ataupun antar kabilah yang lain menjadi terkendali. Padahal, pertentangan kabilah Aus dan Khazraj tersebut telah berlangsung lebih dari dua abad. Sebagai tokoh pembaharu di Madinah Rasul SAW sangat arif dalam menyikapi konflik yang terjadi. Apabila terjadi perkara antara sesama muslim maka diputuskan dengan aturan hukum Islam. Sedangkan, jika pertikaian itu antara orang Arab yang bukan Islam diselesaikan dengan adat yang berlaku pada suku yang bersangkutan. Adapun pertikaian antara sesama Yahudi diselesaikan dengan hukum Taurat. ${ }^{28}$ Semua ini dilakukan Nabi SAW untuk mewujudkan kehidupan yang rukun dan tertib dengan mengetengahkan rasa kewajiban bersama untuk menjaga kepentingan dan keamanan kota Madinah.

Berdasarkan ulasan sejarah di atas, Nabi Muhammad SAW adalah figur yang mampu menyatukan perbedaan di kalangan warga Madinah walaupun latar bekang Rasul SAW. hanya "pendatang" dari Mekah. Keberhasilan ini didasari atas prinsip-prinsip kesetaraan. Selain itu, adanya rasa kebersamaan dan semangat menjaga keutuhan dan ketertiban Madinah membuat seluruh kolompok dan golongan sepakat untuk hidup berdampingan dan rukun antara satu dengan yang lainnya. Dalam perjalanan sejarah 
selanjutnya, semangat yang dibangun Rasul SAW. pulalah yang menjiwai pemerintahan para khulafa' al-rasyidin dalam membangun harmonisasi dalam masyarakatnya di wilayah yang cukup luas.

Potret harmoni antar umat beragama yang dapat dijadikan tempat berkaca selanjutnya adalah tentang sejarah perkembangan Islam di Andalusia. Dalam sebuah buku yang berjudul Surga di Andulisia; Ketika Muslim, Yabudi dan Nasrani Hidup dalam Harmoni dikisahkan betapa Abdurrahman al-Dakhil selaku Khalifah Bani Umayah II berhasil membangun tanah Andalusia yang membuat dunia terkagum-kagum. Sejarah Islam di Andalusia ini mengisahkan suatu wilayah yang penuh romantika tersendiri. Di tangan Abdurrahman al-Dakhil, wilayah Andalusia yang sekarang menjadi bagian Spanyol ini pernah menjadi bak "sepotong surga"; tempat tiga agama besar berkembang. Di dalamnya mereka hidup bersama, damai, saling berdampingan dan secara bersama-sama "memberi makan" pada peradaban dunia. ${ }^{29}$ Uniknya, kisah harmonisnya antar umat beragama yang pernah terbangun di daratan Eropa ini merupakan pengakuan sendiri dari seorang non muslim yang bernama Maria Rosa Menoca atas sejarah Islam yang pernah ada. Sekali lagi, tebinanya harmonisasi antar umat beragama ini tentunya lahir karena rasa ingin membangun dan menjagaga tanah Andalusia sebagai bagian dari kehidupan mereka.

Sejarah tentang pernah terbinanya kehidupan yang harmonis antar penganut agama sebagaimana yang diuraikan sebelumnya merupakan salah satu pengejawantahan dari ajaran Islam yang sungguh sangat toleran. Islam tidak pernah mengajarkan pemeluknya memerangi umat agama lain tanpa alasan yang dibenarkan secara syara'. Bahkan, merusak rumah ibadah agama lain merupakan "kejahatan agama" yang sangat dikutuk dalam Islam. Al-Qur'an sendiri menyatakan dengan lantang dalam surat al-Hajj ayat 40 yaitu sebagai berikut:

${ }^{29}$ Maria Rosa Menoca, The Ornament of The World; How Muslims, Jews and Cristians Created a Culture in Medieval Spain (Bandung: Mizan, 2015), x-xi.

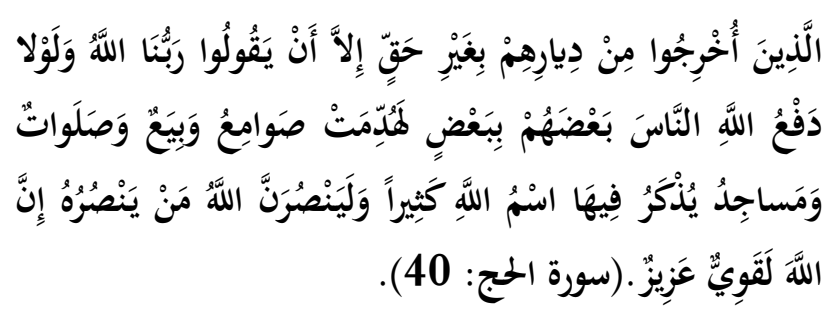

Artinya: "orang orang yang telah diusir dari kampung balaman mereka tanpa alasan yang benar tetapi karena mereka berkata: "Tuban kami banyalah Allab", dan sekiranya Allah menolak sebagian yang lain, tentulah telah dirobobkan biara biara, gereja gereja dan sinagog sinagog serta mesjid mesjid yang di dalamnya banyak disebut nama Allah. Sesunggubnya Allah pasti menolong orang yang menolongNya. Sesunggubnya Allah benar benar Maha Kuat lagi Maha Perkasa”. (QS. Al-Hajj: 40)

M. Quraish Shihab ketika menafsirkan ayat ini menegaskan bahwa sesungguhnya Allah tidak pernah menghendaki kehancuran rumah ibadah. Para ulama pun sepakat menetapkan bahwa menjadi kewajiban umat Islam untuk memeliharanya. Bukan saja memelihara mesjid, tetapi juga rumah ibadah umat umat yang lain seperti gereja dan sinagog. Berdasarkan ayat ini Quraish Shihab berkesimpulan bahwa ajaran Islam memberi kebebasan beragama kepada setiap anggota masyarakatnya dan karena itu menjadi kewajiban pula kepada setiap umat Islam untuk ikut memelihara kebebasan dan ketenangan umat lain dalam melaksanakan ajaran agamanya. Umat Islam tidak boleh mengganggu mereka, sebagaimana umat Islam wajar untuk menuntut bahkan mengambil langkah agar mereka tidak diganggu oleh siapapun. ${ }^{30}$

Senada dengan itu, Haji Abdul Malik Karim Amrullah, seorang mufasir sekaligus pujangga yang populer dipanggil "Hamka" menuturkan bahwa merusak rumah ibadah agama lain sangat bertentangan dengan ajaran Islam. Islam menurut Hamka mengajarkan pemeluknya

30 M. Quraish Shihab, Tafsir Al-Mishbah; Pesan Kesan Dan Keserasian Al-Qur'an (Jakarta: Lentera Hati, 2008), 72. 
menjadi pelindung gereja, biara, sinagog, dan mesjid, bukan merusakkannya. ${ }^{31}$ Peryataan Hamka ini pada dasarnya terkait dengan peristiwa 01 Oktober 1967, malam hari di kota Makasar. Pada saat itu terjadi perusakkan gereja oleh umat Islam yang dilatarbelakangi oleh pernyataan seorang "guru agama Kristen" mengenai Nabi Muhammad SAW. adalah seorang pezina dan seorang yang tolol. Meski pernyataan guru tersebut salah, namun merusak rumah ibadah menurut Hamka adalah tindakan yang sungguh disesalkan.

Meskipun kejadiaannya di era 60an, namun pandangan Hamka ini tentang toleransi beragama tanpaknya masih sangat relevan untuk dikontekstualisasikan di era saat ini. Rentetan kerusuhan antar umat beragama yang disebutkan di awal adalah sikap yang tidak elok bagi keutuhan Indonesia. Jika Hamka masih hidup saat ini, tentunya pernyataan yang sama pasti akan keluar dari mulutnya yang bijak itu.

Berdasarkan penjelasan di atas maka patutlah semangat keislaman dan cinta tanah air adalah alternatif dalam menghidupkan toleransi antar umat beragama. Sudah cukup bukti untuk menguatkan spirit ini. Mulai dari sejarah Piagam Madinah hingga Islam di Andalusia mengilustrasikan dua poin penting dalam menjaga kerukunan umat bergama. Pertama adalah semangat kebangsaan dan cinta tanah air yang menjadi rabitah perbedaan dalam suatu masyarakat yang begitu majemuk. Kedua adalah spirit keislaman yang menjadi bumbu dan warna dalam menghiasi panorama kemajemukan itu. Adanya agama adalah untuk mengarahkan ikatan sebangsa dan setanah air kepada hal hal yang positif dan tentunya dalam bingkai nilai-nilai keilabian.

\section{MENUJU INDONESIA YANG TOLERAN}

Kemajemukan dan keragaman Indonesia adalah sebuah keniscahyaan yang patut disyukuri. Umat Islam sebagai bahagian dari keragaman itu

31 Hamka, Dari Hati Ke Hati (Jakarta: PT. Citra Serumpun Padi, 2002), 159. harus mewarnai keragaman tersebut dengan nilainilai kebaikan yang "universal". Maka peran umat Islam Indonesia sangat dibutuhkan dalam membangun tatanan kehidupan yang adil dan makmur serta diridhai Allah SWT. Kehidupan tersebut sebetulnya adalah model kehidupan masyarakat Madinah yang dipimpin oleh Rasulullah. Sebuah kehidupan yang menjunjung tinggi toleransi beragama.

Terlahir sebagai Muslim sekaligus sebagai anak bangsa Indonesia, kaum muslim di negeri ini memiliki dua tugas dan tanggung jawab dalam kehidupan bermasyarakat. Di antara tanggung jawab itu adalah tanggung jawab "keummatan" dan tanggung jawab "kebangsaan". Tanggung jawab "keumatan" adalah menjalankan misi agama dalam arti menebarkan nilai-nilai keislaman yang toleran dalam kehidupan sehari hari. Sikap seperti ini adalah kewajiban sebagai seorang muslim. Sementara tanggung jawab "kebangsaan" adalah semangat nasionalisme dalam menjaga tanah air dan keutuhan NKRI. Hal ini bukan bermaksud untuk "fanatisme" pada suku bangsa, melainkan adalah tanggung jawab lahiriah yang dimiliki semenjak lahir karena secara geneologis kita merupakan keturunan asli bangsa Indonesia. Islampun sebetulnya mengakui tanggung jawab seperti ini. Meski tidak disebutkan secara jelas dan detail, tapi terdapat banyak isyarat yang menjurus pada persoalan ini. Misalnya dalam surat alHujurat ayat 13 yaitu:

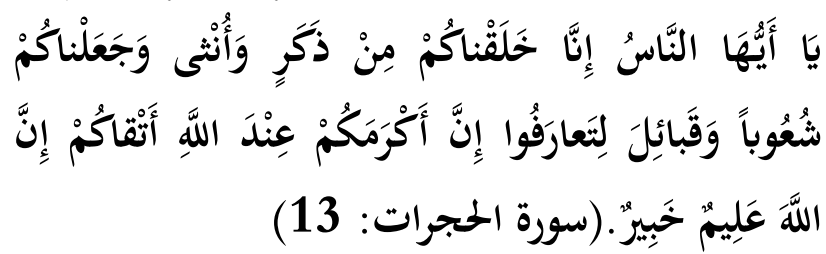

Artinya: "Wahai manusia, sunggub Kami telah menciptakan kamu dari seorang laki-laki dan seorang perempuan, kemudian Kami jadikan kamu berbangsa bangsa dan bersuku suku agar kamu saling kenal mengenal. Sesunggubnya manusia yang paling mulia di sisi Allah adalab siapa yang paling bertakwa di antara kalian. Sesungguhnya 
Allah maha Mengetahui Maha Baik. (QS. Al-Hujurat: 13)

Secara substantif, ayat ini mengisyaratkan pengakuan adanya pluralitas bangsa dan suku. Dengan kata lain, realitas beragamnya budaya dan bangsa yang ada di dunia ini merupakan ayat kauniyah Tuhan. Sementara itu, sikap untuk memiliki nasionalisme dan rasa cinta tanah air dijelaskan dalam sebuah riwayat yang membuktikan ternyata Rasul SAW juga memiliki rasa nasionalisme yang tinggi. Ia adalah nabi yang sangat mencintai tanah airnya; tanah kelahirannya sendiri yaitu Mekah. Adapun hadis menggambarkan kecintaan beliau pada Mekah tersebut sebagaimana diriwayatkan oleh Imam AlTirmizi dengan matan sebagai berikut ${ }^{32}$ :
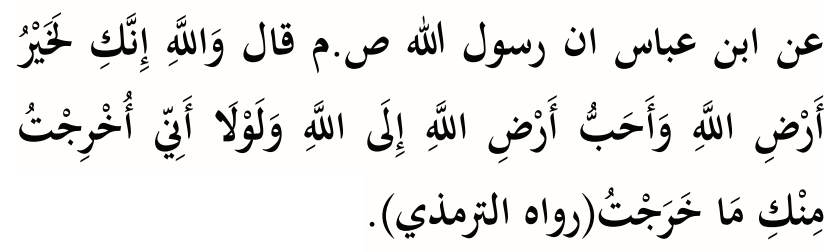

Artinya: "dari Ibn 'Abbas babwasannya Rasulullah SAW pernah bersabda" demi Allah sesunggubnya engkau adalah bumi Allab yang paling aku cintai seandainya bukan yang bertempat tinggal di sini mengusir ku, niscabya aku tidak akan meninggalkannya”. (HR. AlTirmizi)

Oleh karena itu, agaknya mengandalkan ajaran agama yang sifatnya "nofmatif" saja untuk melakukan dialog antar agama sebagai satusatunya alternatif dalam membina dan mengelola pluralitas beragama demi membangun Indonesia yang toleran tidaklah cukup. Sebab, diskursus mengenai agama sangat sarat dengan muatan emosi, kecendrungan dan subjektivitas individu. ${ }^{33}$ Barangkali konflik antar umat agama yang terjadi di sepanjang sejarah negeri ini, berawal dari dialog

32 Wizarah Al-Syuuni Al-Diniyah Lil Jumhuriyah Al-Indonesiah Haiatul Buhutsi wa al-Tanmiyatu AlDiniyah, Mafru'u Tarqiyyah Al-Tasami' Baina Al-Umami AlMutaddinah (Jakarta, 1997), 38.

33 Ahmad Najib, Islam Dinamis; Menggugat Peran Agama, Membongkar Doktrin Yang Membatu (Jakarta: Kompas Media Nusantra, 2001), 3. yang keliru antar agama yang tidak pernah selesai. Oleh sebab itu, di sinilah perlunya mengedepankan nilai-nilai kebangsaan dan semangat cinta tanah air. Nilai-nilai ini harus diletakkan di atas semua kepentingan termasuk kepentingan agama.

Perlunya sikap nasionalisme saat ini beranjak dari semakin pudarnya rasa sebangsa dan setanah air. Gejala tersebut sangat terasa dan tampak sekali dari kalangan muda yang terpapar ideologi impor (radikalisme) yang merusak mental dan pikiran. Kesalahan ini sebetulnya terletak di tangan kita yang sebagai bangsa tidak mampu merawat dan menjaga nilai nilai kebangsaan kita sendiri dengan baik. Makanya, tidak heran kasus intoleransi beragama di kalangan anak muda saat ini mulai jamak terjadi. Temuan Komnas HAM sejak 2012-2018 menyebutkan indeks kecendrungan intoleransi di kalangan generasi semakin meningkat yaitu dari yang tadinya hanya 201\% sekarang mencapai 50\%. Sikap intoleransi ini dikatakan semakin menguat justru di kalangan anak muda terdidik. ${ }^{34}$ Anak muda yang secara psikologis sedang mencari jati diri ini akhirnya menjadi mangsa segar bagi "ideologi non kebangsaan" yang radikali itu. Tidak aneh apabila mereka lebih kenal sosok Hasan al-Bana dari pada Agus Salim. Mereka lebih memuja ide-ide Karl Marx dibanding ideologi Hamka. Berbeda dalam ideologi barangkali tidak menjadi persoalan, namun jangan sampai ideologi itu merusak kebersamaan dan mengalahkan rasa cinta kepada sesama anak-bangsa.

Dengan demikian, dalam membangun Indonesia yang toleran diperlukan dukumham kekuatan para pemuda. Sebagaimana diketahui bahwa Indonesia yang toleran merupakan cita-cita besar di masa yang akan datang. Oleh karenanya, cita-cita itu bergantung pada kalangan pemuda Indonesia. Sebab, dahulunya bangsa ini

34 Komnas HAM, "Kecenderungan Sikap Intoleransi Menguat Di Kalangan Anak Muda Terdidik"," Kompas.Com, n.d., https://nasional.kompas.com/read/2019/11/15/18195711 /komnas-ham-kecenderungan-sikap-intoleransi-menguatdi-kalangan-anak-muda . 
ditemukan dan diusahakan oleh sebagaian besar anak-anak muda. Maka, untuk saat ini mereka pula lah yang akan memperjuangkan dan menentukan nasip bangsa Indonesia ke depannya.

Penanaman nilai-nilai kebangsaan itu bisa dilakukan dalam berbagai aspek. Misalnya, melalui pemutaran film sejarah para pendiri bangsa. Di era Soeharto, metode ini telah dipraktikkan dan berhasil. Pada tanggal 30 September selalu diputarkan film G 30S/PKI setiap tahunnya. Penayangan film ini menjadi instrumen penting dalam melakukan indoktrinasi tentang bahaya ideologi Komunisme di Indonesia. melalui film ini juga digambarkan kekejaman PKI dan akhirnya mereka dianggap sebagai pengkhianat bangsa. Terlepas dari benar atau salahnya konten film tersebut, namun langkah ini cukup efektif dalam membendung ideologi komunis yang sangat bertentangan dengan ideologi Pancasila. Dalam konteks sekarang, penerapan metode ini dapat direfleksikan dalam bentuk penayangan film sejarah perjuangan para pahlawan bangsa. Motode ini lebih cocok dengan generasi dan era digital saat ini untuk menanamkan rasa cinta terhadap bangsa dan tanah airnya.

Pentingnya pemutaran film sejarah bangsa bertali temali dengan upaya membangun kesadaran berbangsa dan bernegara. Selain itu, metode ini juga sebagai upaya memelihara sejarah bangsa. Sebuah bangsa yang tidak lagi mengenal sejarah bangsanya sendiri tentu akan mudah diadu domba pihak luar. Pentingnya membangun kesadaran sejarah dalam berbangsa ini sejalan dengan pesan pemimpin revolusioner Indonesia, Bung Karno, yang mengingatkan bahwa jangan lupakan sejarah atau dikenal dengan sebutan "Jas Merah". Pesan founding father tersebut mestinya menjadi renungan bersama oleh anak anak bangsa bahwa sejarah itu penting dalam menanamkan nasionalisme. Bayangkan, apabila generasi muda tidak lagi mengenal sejarah dan para pendiri bangsanya maka kemana negara ini akan mereka bawa di masa depannya?

Selain itu, melalui nyanyian lagu kebangsaan juga menjadi metode yang menarik dalam membangun kesadaran berbangsa. Lagulagu kebangsaan semestinya tidak lagi diputar ketika forum-forum resmi. Lagu kebangsaan harus dijadikan konsumsi wajib bagi masyarakat terutama generasi muda dalam aktivitas seharihari. Tentu akan menjadi sebuah kekhawatiran ketika masyarakat lebih populer dan hafal lagulagu bangsa lain seperti tentang jihad di Palestina atau nyanyian yang berirama "Padang Pasir" dibanding lagu kebangsaannya sendiri. Seandainya terjadi maka ini pertanda buruk bagi nasionalisme dan kebangsaan kita. Nasionalisme akan diletakkan di bawah kepentingan ideologi pribadi dan kelompoknya. Lalu bagaimana mungkin toleransi akan terwujud jika kondisinya sudah seperti ini. Boleh jadi Indonesia akan luluh lantak layaknya seperti mayoritas negara Timur Tengah, seperti Syiria, Libia, Palestina, dan lain-lain.

Sebaliknya, apabila kesadaran sejarah dan jiwa nasionalisme sudah tertanam sejak dini dalam setiap diri generasi muda hari ini maka tentu citacita menuju Indonesia yang toleran di masa mendatang dapat terwujud. Kesadaran ini lah yang dari awal disebut sebagai ukhuwah wathaniyah. Melalui pendekatan nilai-nilai persatuan di dalamnya kita dapat merawat keragaman terutama perbedaan agama dan keyakinan dalam satu ikatan kebangsaan, sesuai dengan falsafah bangsa yaitu "bbineka tunggal ika".

\section{PENUTUP}

Pada akhirnya, harus diakui bahwa intoleransi beragama hanyalah "limbah politk" yang merusak kerukunan umat beragama. Agama tidak pernah mengajarkan saling berperang dan membunuh satu sama lain. Dialog antar umat beragama dengan mengedepankan emosional dan kebenaran relatif masing-masing agama tidak akan mampu melahirkan sikap toleransi beragama. Justru metode tersebut malah akan memancing konflik antar sesama. Oleh karena itu, sebagai bangsa yang beragam, perbedaan agama mesti dibingkai dalam rasa kebangsaan dan cinta tanah air atau "Ukhuwah Wathaniyah". Kecintaan pada agama mestinya disejajarkan dengan rasa 
nasionalisme ini. Bahkan, adakalanya salah satu dari keduanya mesti mengalah. Sikap semacam ini pada hakikatnya adalah menjalankan sunah Rasulullah SAW. Praktik semacam ini dalam sejarah Islam pernah dipraktikkan Rasul SAW. ketika di Madinah. Dengan kata lain, siapa saja yang mengaku muslim tentu wajib mengikuti sesuatu yang sudah dipraktikkan Rasul SAW. ini.

\section{DAFTAR KEPUSTAKAAN}

Abbas. "Agama Dan Konflik Dalam Masyarakat Di Indonesia." Shautut Tarbiyah-IAIN Kendari 18, no. 2 (2012): 10-17.

Abdullah, M Amin. "Pengajaran Kalam Dan Teologi Di Era Kemajemukan.” Jurnal Tashwirul Afkar, no. 11 (2001): 1-20.

Ahmad, Haidlor Ali. Dinamika Kehidupan Keagamaan Di Era Reformasi. Edited by Haidlor Ali Ahmad. Jakarta: Litbang dan Diklat Kemenag, 2010.

Al-Diniyah, Wizarah Al-Syuuni Al-Diniyah Lil Jumhuriyah Al-Indonesiah Haiatul Buhutsi wa al-Tanmiyatu. Mafru'u Tarqiyyah AlTasami' Baina Al-Umami Al-Mutaddinah. Jakarta, 1997.

Baidi, Baidi. "Agama Dan Multikulturalisme: Pengembangan Masyarakat Melalui Pendekatan Agama." Millab ed, no. khus (December 20, 2010): 1-29. https://doi.org/10.20885/millah.ed.khus.art 1.

Daulay, M. Zainuddin, ed. Mereduksi Eskalasi Konflik Antar Umat Beragama Di Indonesia. Jakarta: Litbang dan Diklat Kemenag, 2012.

Halili. "Siaran Pers Setara Institute, 'Melawan Intoleransi Di Tahun Politik: Kondisi Kebebasan Beragama/Berkeyakinan Dan Pemajuan Toleransi Di Indonesia Tahun 2018." Jakarta, 2019.

HAM, Komnas. "Kecenderungan Sikap Intoleransi Menguat Di Kalangan Anak Muda Terdidik"." Kompas.Com, n.d. https://nasional.kompas.com/read/2019/1 1/15/18195711/komnas-hamkecenderungan-sikap-intoleransi-menguatdi-kalangan-anak-muda .

Hamka. Dari Hati Ke Hati. Jakarta: PT. Citra Serumpun Padi, 2002.

Hasyim, Umar. Toleransi Dan Kemerdekaan Beragama Dalam Islam Sebagai Dasar Menuju
Dialog Dan Kerukunan Antar Agama. Jakarta: PT. Bina Ilmu, 1979.

Ismail, Faisal. Republik Bbineka Tunggal Ika; Mengurai Isu-Isu Konflik, Multikulturalisme, Agama Dan Sosial Budaya. Jakarta: Litbang dan Diklat Kemenag, 2012.

Jacques, Bertrand. Nationalism and Ethnic Conflict in Indonesia. Cambridge: Cambridge University Press, 2004.

Kafid, Nur. "Agama Di Tengah Konflik Sosial: Tinjauan Sosiologis Atas Potensi Konflik Keberagaman Agama Di Masyarakat." AlA'raf : Jurnal Pemikiran Islam Dan Filsafat 12, no. 1 (June 30, 2015): 1-13. https://doi.org/10.22515/ajpif.v12i1.1180.

Mahsun, Mahsun. "Tragedi Di Pulau 'Seribu Mesjid': Konflik Agama Atau Perlawanan Budaya?" Antropologi Indonesia, no. 63 (July 21, 2014): 81-90. https://doi.org/10.7454/ai.v0i63.3403.

Menoca, Maria Rosa. The Ornament of The World; How Muslims, Jews and Cristians Created a Culture in Medieval Spain. Bandung: Mizan, 2015.

Muqoyyidin, Andik Wahyun. "Potret Konflik Bernuasa Agama Di Indonesia (Signifikansi Model Resolusi Berbasis Teologi Transformatif)." Analisis XII, no. 2 (2012): 315-40.

Najib, Ahmad. Islam Dinamis; Menggugat Peran Agama, Membongkar Doktrin Yang Membatu. Jakarta: Kompas Media Nusantra, 2001.

Pamungkas, Arie Setyaningrum, and Gita Octaviani. "Aksi Bela Islam Dan Ruang Publik Muslim: Dari Representasi Daring Ke Komunitas Luring." Jurnal Pemikiran Sosiologi 4, no. 2 (November 6, 2017): 65-87. https://doi.org/10.22146/jps.v4i2.28581.

Penyusun, Tim. Proyeksi Penduduk. Indonesia Tabun 2010-2035. Jakarta: BPS, 2013.

Prasutomo, Engki, Hengki Wijaya, and Ivan Th. J Weismann. "The Role of Public Sphere According to Jurgen Habermas's Perspective for Multicultural Societies in the Indonesia Context." FUADUNA: Jurnal Kajian Kegamaan Dan Kemasyarakatan 02, no. 02 (2018): 43-54.

Qodir, Zuly. "Kaum Muda, Intoleransi, Dan Radikalisme Agama." Jurnal Studi Pemuda 5, no. 1 (August 9, 2018): 429-45. https://doi.org/10.22146/studipemudaugm. 
37127.

Shihab, Alwi. Examning Islam in The West; Addessing Accusation and Correcting Misconceptation. Jakarta: Gramedia, 2011.

Shihab, M. Quraish. Tafsir Al-Mishbab; Pesan Kesan Dan Keserasian Al-Qur'an. Jakarta: Lentera Hati, 2008.

Sudarto. "Recognisi Agama Lokal Prasyarat Menuju Demokrasi Majemuk." FUADUNA: Jurnal Kajian Kegamaan Dan Kemasyarakatan 02, no. 02 (2018): 92-105.

Syukron, Buyung. "Agama Dalam Pusaran Konflik (Studi Analisis Resolusi Terhadap Munculnya Kekerasan Sosial Berbasis Agama Di Indonesia)." Ri'ayab: Jurnal Sosial Dan Keagamaan 2, no. 01 (December 14, 2017): $1-28$. https://doi.org/10.32332/riayah.v2i01.960.

Tim Penyusun. Statistik Indonesia 2019. Jakarta: BPS, 2019.

Wahid, Yenny Zannuba. Laporan Tahunan Kebebasan Beragama Berkeyakinan 2018. Jakarta: The Wahid Institute, 2018. 